\title{
Constructing Innovation and Entrepreneurship Education System for the Cultivation of Innovative Talents in Computer Major
}

\author{
Chun Jiao ${ }^{1, *}$ \\ ${ }^{1}$ School of Intelligent Science and Information Engineering, Xi'an Peihua University, Xi'an, Shaanxi 710125, China \\ *Corresponding author. Email:2024988445@qq.com
}

\begin{abstract}
To build an innovative and new industrialized country, it is necessary to continuously and deeply promote the reform of innovation and entrepreneurship education in colleges and universities of our country in order to train a large number of computer professionals with innovative spirit and entrepreneurial ability for our country. This article focuses on the overall ideas and specific methods of constructing the innovation and entrepreneurship education system in computer major.
\end{abstract}

Keywords: innovation and entrepreneurship education, computer major, innovative talent

\section{INTRODUCTION}

The cultivation of innovative and entrepreneurial talents has put forward higher requirements for domestic colleges and universities to strengthen higher education reform and the cultivation of innovative talents. Carrying out innovation and entrepreneurship education is also an important part of the training of computer application talents currently [1]. It is necessary to organically integrate innovation and entrepreneurship education with professional education, engineering practice education and second classroom education, so that the concept and the content of innovation and entrepreneurship education is able to run through the entire process of computer professional training.

\section{The Necessity of Strengthening the Cultivation of Innovative Talents in Computer Major}

In order to accelerate the development of the national information society, implement the development strategy of building an innovative and new industrialized country, and meet the development needs of new economies, new technologies and new industries in the era of "Internet +", it is imperative to strengthen the cultivation of high-quality computer professionals.

First, information technology and information resources are an important part of our country's social development and various undertakings. The information industry has become a pillar and basic industry in China. Computer professionals play a vital role in promoting the process of national informatization.

In the second aspect, new technologies such as mobile Internet, cloud computing, big data, Internet of Things and artificial intelligence have become important driving forces for our country's new economic development and a new round of technological and industrial revolution. These new technologies are closely related to computer science and computer technology. Computer professionals have become the main force which are leading the future of new technologies, interdisciplinary integration and cross-border integration.

The third aspect, in 2015 , our country formally proposed to promote mass entrepreneurship and mass innovation as a national-level development strategy. Undergraduates are a new force to implement the national innovation-driven development strategy and promote mass entrepreneurship and innovation. Therefore, there is an urgent need to accelerate the reform of higher education in our country, and continuously deepen the reform of innovation and entrepreneurship education in colleges and universities, strengthen the cultivation of undergraduates' innovative spirit in order to build a large-scale, innovative and entrepreneurial talent team.

Fourthly, under the current situation, computer application talents also need to have innovation and entrepreneurship capabilities. Many local colleges and universities place the goal of talent training on the cultivation of high-quality applied technical talents on the front line of production services. These applied technical talents also need to adapt to the requirements of local economic and social development and regional economic transformation for innovative and entrepreneurial talents, that is, they need to have the technical skills that meet the needs of the job, have the entrepreneurial quality to find market needs, and have the ability to innovate based on professional knowledge [2].

In summary, under the new situation, in the face of new economic development and a new round of technological and industrial revolution, and in the face of our country's development strategy of building innovative and new industrialized country, as well as "Made in China 2025" 
and "Artificial Intelligence 2.0 ", " Industry 4.0 ", " Internet + ", " Mass Entrepreneurship, Mass Innovation ", " the Belt and Road Initiatives " and other major strategic plans, our country's higher engineering education needs to take on a new historical mission to provide sufficient innovative talents in computer major for our country's sustainable and high-quality development.

\section{The Current Problems of Our Country's Colleges and Universities in Innovation and Entrepreneurship Education}

Innovation and entrepreneurship is the root of a country's development and the soul of a nation's revitalization. The current trend of mass entrepreneurship and mass innovation has been formed in our country. Governments at all levels and local colleges and universities have formulated policies, systems and documents to promote the reform of innovation and entrepreneurship education. In general, in response to national requirements, the current situation in which colleges and universities actively carry out innovation and entrepreneurship education for undergraduates has taken shape and has shown a trend toward deep development.

But at the same time, we must also be soberly aware that the innovation and entrepreneurship education of colleges and universities in our country is gradually entering the deep water area, and some bottlenecks have been encountered in the development. There are mainly the following problems. First, although the importance of innovation and entrepreneurship education for undergraduates has been deeply understood, the positioning of innovation and entrepreneurship education is not high enough, the concept is not mature enough, and the ideas are not open enough. Innovation and entrepreneurship education has not been incorporated into the core level or important content of the entire education system in some colleges and universities of our country. In the second aspect, a considerable number of colleges and universities have not yet established a comprehensive, scientific and systematic education system for undergraduates' innovation and entrepreneurship. The innovation and entrepreneurship courses in some colleges and universities are still dissociated from the professional course system and practical teaching system of undergraduates, and they are still in a state of marginalization. For example, in some colleges and universities the innovation and entrepreneurship education for undergraduates is mainly through several related courses, or several related lectures, or directly to replace the practical teaching of innovation and entrepreneurship education with the innovation and entrepreneurship design contest. The innovation and entrepreneurship curriculum lacks pertinence, and the theory teaching and practical teaching of innovation and entrepreneurship education lack unity. In the third aspect, the faculty who carries out innovation and entrepreneurship education for undergraduates are relatively weak. Teachers who undertake innovation and entrepreneurship education courses should have certain entrepreneurial management and project operation experience, but due to the limitations of the current teacher structure in our colleges and universities, there are fewer mentors with relevant experience and from enterprises, resulting in a certain discount in the effect of innovation and entrepreneurship education. Fourthly, although most colleges and universities have formulated policies or mechanisms to promote the reform of innovation and entrepreneurship education for undergraduates, which are mostly at the macro level or just are guiding documents, and most of them are not specific enough or lack implementation rules or implementation plan at the specific operational level. In the fifth aspect, the practical teaching of innovation and entrepreneurship education for undergraduates in some colleges and universities is relatively weak. For example, there is no special practice base for innovation and entrepreneurship education, or only some innovation training projects are carried out, entrepreneurship training projects and entrepreneurship practice projects are not carried out in substance. There is still a lack of practical courses for entrepreneurial elements, and there is also a lack of organic integration between professional practice teaching and the content of innovation and entrepreneurship education [3].

In summary, although the nationwide innovation and entrepreneurship education of undergraduates has a good foundation, and has a good guarantee mechanism and policy support. However, quite a lot of local colleges and universities still have many weak points in some key issues of innovation and entrepreneurship education, which requires colleges and universities in our country to effectively explore and solve the above specific problems combining with their actual conditions.

\section{Construction of the Innovation and Entrepreneurship Education System in Computer Major}

The cultivation of innovative talents in computer major is aimed at improving the basic qualities of undergraduates in innovation and entrepreneurship, and cultivating innovation spirit and entrepreneurial ability, and its core lies in the construction of the innovation and entrepreneurship education system in computer major. The main ideas for constructing the innovation and entrepreneurship education system are to fill in shortcomings, restructure resources, strengthen mechanisms, rely on the school-enterprise cooperation platform, deeply integrate innovation and entrepreneurship education with professional education, and strengthen teaching effect through practical projects. Focusing on the construction of the innovation and entrepreneurship education system in computer major, the idea and the content of innovation and entrepreneurship education are integrated into the entire process of professional teaching, 
so that the innovation and entrepreneurship education are integrated with professional education tightly.

The following five specific measures can be taken.

First, aiming at the deep-seated problems in the reform of innovation and entrepreneurship education in colleges and universities of our countries, guided by our country's programmatic documents on innovation and entrepreneurship education reform, following the basic laws of higher education and the CDIO engineering education concept, with innovative thinking and entrepreneurial awareness and innovation and entrepreneurship capabilities are the focus and core of talent training, it is necessary to systematically sort out and integrate incentive policies, resources and elements on innovation and entrepreneurship education at all levels.

The second point is to explore the collaborative education mechanism of school-enterprise cooperation and the integration of industry, education and research around the cultivation of innovative thinking, entrepreneurial awareness and innovative and entrepreneurial capabilities. It is necessary to focus on building out-of-school practice bases for innovation and entrepreneurship education, to construct innovation training projects, entrepreneurship training projects and entrepreneurship practice projects suitable for undergraduate participation relying on the innovation and entrepreneurship education practice bases inside and outside universities.

The third point is to reform the teaching management model, teaching methods and practical teaching. Under the guidance of teachers, undergraduates independently choose the research directions from interests, autonomously choose engineering practice projects and other autonomous learning models. It is necessary to carry out heuristic, inquiry, discussion, and participatory teaching, and to promote teaching with scientific research, promote the interaction between scientific research and teaching, and transform scientific research results into teaching content in a timely manner, and to strengthen the design and application of comprehensive and autonomous practical projects to support undergraduates to carry out research-based learning, innovative research and development activities.

The fourth point is to adjust the talent training goals for computer major, so that professional education and innovation and entrepreneurship education can be organically unified in talent training and development [4]. It is necessary to incorporate innovation and entrepreneurship education into professional education, engineering practice education and the second classroom education system, and build a multi-education system suitable for the cultivation of innovative professionals in computer major, and deeply integrate the concepts and the content of innovation and entrepreneurship education into the main channel of professional teaching, and throughout the entire process of computer professional training. It is possible to build an innovation and entrepreneurship education system for computer major by setting up compulsory courses, elective courses, and practical courses for innovation and entrepreneurship. The compulsory courses focus on the basic theoretical study of innovation and entrepreneurship; the elective courses focus on the personalized cultivation of innovation and entrepreneurship; the practical courses rely on the innovation and entrepreneurship education practice bases inside and outside universities to enable undergraduates to participate in various innovation training projects, entrepreneurship training projects and entrepreneurship practice projects. The second classroom education should be regarded as an important form of innovation and entrepreneurship education. Through conducting various second classroom education activities, it is able to promote the training and cultivation of undergraduates' innovative thinking, stimulate undergraduates' innovative vitality. In the specific implementation process, it is necessary to carry out teaching process design around innovative projects and entrepreneurial projects, and select suitable teaching content and teaching methods [5]. It is necessary to pay attention to the difference between entrepreneurial practice projects and professional practice projects. For entrepreneurial practice projects, the emphasis should be placed on the cultivation of innovative thinking, entrepreneurial capabilities, teamwork, and operational management capabilities, at the same time, professional training should be also taken into account.

The fifth point is to build a team of high-quality, full-time and part-time, double-qualified innovation and entrepreneurship mentors. Due to the lack of practical experience in innovation and entrepreneurship and experience in business operations, professional teachers lack the ability to guide entrepreneurial practice. By recruiting entrepreneurial instructors with entrepreneurial experience and enterprise experts with business operation experience from outside universities, we can form the mentor team of innovation and entrepreneurship education together with the professional teachers in school. The recruitment of instructors outside universities can take a variety of flexible forms such as visiting professors, lecture professors, special teachers for courses [2] Eventually an entrepreneurship team outside universities consisting of well-known entrepreneurs, well-known scholars, successful alumni and venture capitalists will be formed. Entrepreneurship instructors, enterprise experts and professional teachers can jointly formulate talent training plan and teaching implementation programs for innovation and entrepreneurship courses to ensure that the courses or practice projects of innovation and entrepreneurship education are able to meet market development needs. At the same time, the content and the direction involved in the courses and the practice projects also need to conform to the development direction of computer technology. In addition, to further strengthen the construction of double-qualified teachers for innovation and entrepreneurship education, we can regularly organize special training on innovation and entrepreneurship education in school, and organize teachers to regularly attend training, internships, on-the-job exercises or directly participate in research or development projects of enterprises to improve the ability and the level of the teachers to guide practical projects. 


\section{CONCLUSION}

Carrying out innovation and entrepreneurship education is an inevitable requirement for China to build an innovative and new industrialized country. Constructing the innovation and entrepreneurship education system for computer major is conducive to the organic integration of professional education and innovation and entrepreneurship education, and to improve the cultivation quality of innovative talents in computer major, and to provide talent and intellectual guarantee for technological and industrial innovation.

At the same time, under the current situation, building the systematic and scientific innovation and entrepreneurship education system for computer major is also conducive to cultivating innovative talents that adapt to social development for industrial development and market demand, and also has great practical significance for improving the training quality of applied talents in local colleges and universities.

\section{REFERENCES}

[1] JI Hong, FEI Zhi-yong, ZHANG Gen-hua, QIAN Yi-ping, ZHOU Bu-kun, Practice and Reflection of Innovation and Entrepreneurship Education in Local Applied Universities, Research and Exploration in Laboratory. 2016(8):185-189.

[2] JI Hong, GU Yong-an, ZHANG Gen-hua, PAN Qiyong, FEI Zhi-yong, Exploration of Innovation and Entrepreneurship Education from the Perspective of Training Applied Talents, Jiangsu Higher Education. 2016(4):77-80.

[3] LIU Yan, LIN Xiang-you, LU Jia-hui, MENG Qing-fan, TENG Li-rong, Reform Practice Teaching and Promote Innovation and Entrepreneurship Education, Chinese University Teaching. 2016(7):84-86.

[4] ZHAO Zhi-chao, WU Tie-feng, Discussion on Innovation and Entrepreneurship Education Mode of Computer Major in Colleges and Universities, Pioneering with Science \& Technology Monthly. 2017(7):86-87.

[5] GOU He-ping, JING Yong-xia, WU Lan, CHEN Lili, Exploration of Innovation and Entrepreneurship Education for Computer Major under the Background of "Internet +", Journal of Lanzhou Institute of Education. 2019(10):104-105,114. 